\title{
Endogenous conflict resolution mechanisms of the San people at Platfontein
}

\author{
MY GEBREGEORGIS
}

\begin{abstract}
The objective of this study was to explore the endogenous conflict resolution mechanisms and practices of the San people at Platfontein, South Africa. To this end, data were collected from 304 interviews and 26 focus group discussions. The collected data were analysed through Inductive Thematic Analysis. The findings show that the San people have endogenous conflict resolution mechanisms which basically aim at restoring peace and harmony within the community. The endogenous mechanisms were found to be fairly participatory and supplementary to the state machineries that work for justice, peace and harmony. However, the conflict resolution mechanisms of the San people are currently weakening due to the impact of modernisation and the leadership dispute among the sub-groups of the community.
\end{abstract}

Key words: conflict, dispute, endogenous, Platfontein, San

\section{Introduction}

The literature on the San people of Southern Africa seems to lack consistency in naming the people, their languages and their numbers. "Categories used by various ethnologists and linguists are not consistent. Names of people and languages are further confused by the different local and popular names and varieties of spelling." Some of the resources barely specify the scope of their claim, regardless of the presence of diverse groups of San in the region.

Different groups of people name the San people differently. "The European settlers called these people: Bosjesman, Soaqua, Bushmen, and other names. The Black Bantu-speaking people referred to them as Basarwa, Abathwa, Baroa, etc. depending on the language of the

2 O Jenkins, The!Kung Bushmen, 2006, http://orvillejenkins.com/profiles/kung.html p.1. 
Black people." According to the same institute, the community currently prefers their name to be "San" and their gene and language stock to be identified as "Khoe-San."

The term "San" encompasses a diverse group of hunter-gatherers in Southern Africa who have genealogical, historical and linguistic connections. Though sources agree that the term originates in Khoekhoe, they offer different interpretations of its meaning. For example, SASI says it "probably refers to people without cattle or people who forage for their food". 5 According to Kwekudee, however, the meaning of "San" in the Nama language of the Khoikhoi is "outsider". They were so labelled to isolate them from the Khoikhoi, who claim to be the First People of the region. ${ }^{6}$

While Jenkins estimates the San population to be around $50000,{ }^{7}$ Desert of the Skeletons raises the figure to $100000 .^{8}$ The San people "are the best model we have for the huntergatherer lifestyle that saw so many generations through the Stone Age, and it is tempting to say that the history of the later Stone Age is the history of the San". ${ }^{\circ}$ Genetic and archaeological evidence also tends to favour this assumption. The gene pattern of the KhoeSan, which dates back 80000 years, is believed to be the oldest in the world. Cultural practices such as ostrich eggshell beads, shell ornaments, the bow and arrow and rock art, which still exist among the San people, were being practised some 25000 years ago by the ancestors of these same people. ${ }^{10}$

The San are known for their deep knowledge of flora and fauna. They can identify and use 55 species of animal and 100 edible plant species. They used to live by hunting these animals and gathering the plants. They invented their own special bow and arrow which allows them to hunt successfully. These days, a few members of the community in the most remote areas of the Kalahari Desert still follow their traditional lifestyle. ${ }^{11}$ Otherwise, "for various reasons, but notably as a result of the creation of the Kalahari Gemsbok National Park in 1931, the majority of San people were forced to give up their hunting and gathering lifestyle." 12 Some of them rely on benefits they receive from their respective governments. Though the people do not easily adopt the practice, governments are also encouraging them to be engaged in agricultural activities.

As hunter-gatherers, the San lead their lives in small mobile communities that encompass four or five hunting men along with their wives, children and other close relatives. However, groups can meet at certain periods in the year for social events such as marriage arrangements,

South African San Institute (SASI), History, 2009, http://www.san.org.za/history.php p.1.

SASI, op.cit., p.1.

SASI, op.cit., p.1.

Kwekudee, Trip down memory lane, 2013, http://kwekudee-tripdownmemorylane.blogspot.com/

Jenkins,op. cit.

Desert of the Skeletons, 2013, http://www.youtube.com/watch?v=J2UXX9yAQGY

South African History Online (SAHO), San hunter-gatherer society in the Later Stone Age, 2000, http://www.sahistory.org.za/people-south-africa/san p.1.

SAHO, op. cit.

Desert of the Skeletons.

SASI, op. cit., p.1. 
exchange of gifts and news. Wives build temporary huts from long grass and branches they find nearby. "Hunting is a team effort and the man whose arrow killed the animal has the right to distribute the meat to the tribe members and visitors." ${ }^{13}$ The community gives due respect to the elderly. After a killing, the oldest man in the community that shares the food has to test it first. ${ }^{14}$

One of the group of hunters can be an expert on certain parts of their socioeconomic activities such as spiritual healing, shooting and tracking. Otherwise, no one is given special importance in terms of leadership status. "Their social structure is not tribal because they have no paramount leader and their ties of kinship are fairly relaxed." 15 Thus it can be surmised that the appointment of traditional leaders in most San communities began after their contact with other communities.

The San believe that there is one Great God, with less mighty gods that have wives and children. Gaoxa, the Great God, is creator of many things and is also in many things. ${ }^{16}$ The San people believe that Gaoxa himself lives on the Tsodilo hills with all his cattle, sheep, goats and many other different animals. The San's story in this regard says:

... a man had two wives, but he loved one wife more than the other, and this caused a big quarrel. The one he didn't love hit him on the head, causing a deep wound. Then she ran off into the desert. But the Great God, Gaoxa, decided that because there was no peace among them, he must turn them all into stone. The man became the largest of the hills; the unloved wife became the smallest hill that stands alone; and the loved wife, with her children, became the cluster of hills in the middle. ${ }^{17}$

This legend indicates how the San people love peace and harmony. The San, like other precolonial Africans, used to resolve their disputes through discussion and group consensus. ${ }^{18}$

\section{The San and their relations with other people}

The San people are naturally peaceful and friendly. They "call themselves zhu twa si, 'the harmless people,' in contrast to non-San, whom they call zosi, 'animals without hooves,' meaning they are as dangerous as predator animals." 19 "Before the advent of trade with Bantu or white settlers, all tools, construction materials, weapons or clothes were made of plants or

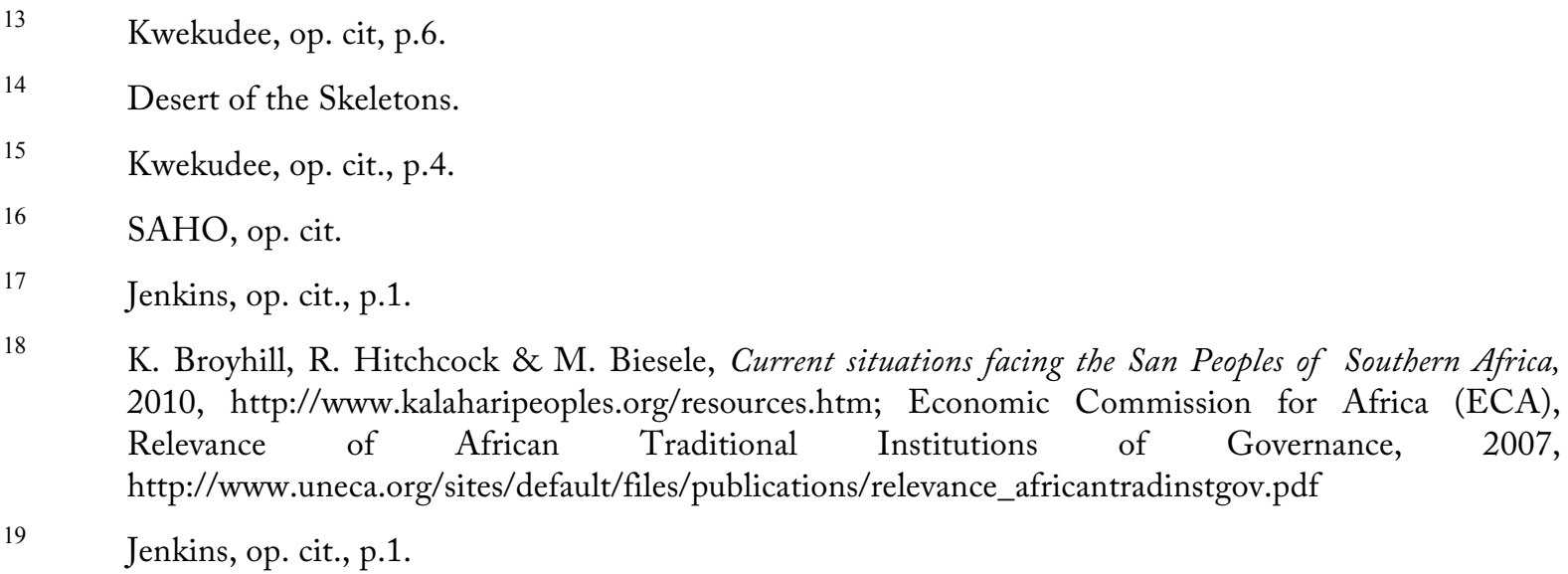


animal products." ${ }^{20}$ When they hunt, the San people take care not to attack the females and young of their prey. ${ }^{21}$

However, as hunter-gatherers, they could not settle permanently in one area. This way of life brought them into conflict with the Bantu settlers and European colonisers. At different times, they fought against the domination of the settlers and the colonisation of the conquerors; nevertheless, due to their small population and lack of weapons, they could not resist the attacks of the colonisers. Following the attacks, those wo survived the mass extinctions were forced to stop roaming freely from place to place and had to live in a restricted area of dry land in Southern Africa. Some of them were either enslaved to work on the farms of the black and white farmers, or were made to adopt their neighbouring black farming communities' lifestyles and intermarry with them. ${ }^{22}$

South Africa is one of the homes of the San people. Of the members of the San community in Southern Africa, the !Xun and Khwe at Platfontein are "the two largest San groups in South Africa." 23 These groups are part of the San community that was an ally of the Portuguese and the South African Defence Force (SADF), who opposed black people who were fighting for the independence of Angola and Namibia respectively. The San were made to resettle in South Africa in 1990 for fear of retaliation from the ex-freedom fighters, who had become members of the governments of their respective countries. The objective of this study was to explore the conflict resolution mechanisms and practices of this community.

\section{Methodology}

In order to access and assess the community's conflict resolution mechanisms and practices, a qualitative research approach was used. Data were collected through two methods: interviews and focus group discussions. The data were collected by trained field researchers recruited from the community and the author's in-depth interviews with selected members of the community: 304 community members were interviewed and 26 focus group discussions were conducted. The interviewees and discussants were systematically selected in such a way that both sexes, all blocks of the settlement and all sub-groups of the community were represented. The focus groups, which comprised five to seven discussants, were heterogeneous. The research participants were people from the community who know and live in the culture. The data were first recorded in the mother tongue of the research participants and subsequently translated into English by hired professionals who know the community's culture. Inductive Thematic Analysis was used to determine the target community's endogenous conflict resolution mechanisms from the discourse of the research participants on the topic. This method of analysis was specifically chosen to find, code and sort evolving themes from the data. An iterative procedure of data analysis was employed

\footnotetext{
$20 \quad$ Kwekudee, op. cit., p.1.

21 Desert of the Skeletons.

22 Jenkins,op. cit.; SASI, op. cit., p.1.

23 Roger Chennells \& Aymone Du Toit, The Rights of Indigenous Peoples in South Africa, in R Hitchcock \& D Vinding (eds), Indigenous Peoples' Rights in Southern Africa, 2004, www.iwgia.org/iwgia_files.../0119_SouthernAfricaDoc110Complete.pdf p.98.
} 
until the steps and procedures of the intra-community endogenous conflict resolution institutions were fully explored.

\section{Conflict within the San community}

While they were hunter-gatherers, the San had no serious reason to engage in inter-group conflicts. Being small groups, they lived in patches of trees and bushes. The zone in which they did not live was a hunting area that was open to any group of hunters. No group had exclusive rights to particular hunting areas. As a result, no group was compelled to defend its hunting territory. ${ }^{24}$ They used to live "on their own. There was nobody who told them what to do and what not to do. If a person was willing to go and hunt, he just ... went to the bush and hunted whatever animal he wanted to." ${ }^{25}$

These days, however, the San people who have ceased hunting and gathering are experiencing conflicts that emanate from their lifestyle change and subsequent poverty. The income sources of the community are disability grants and child support and unemployment in Platfontein is high. Most of the matriculated youth cannot proceed to the next academic level or an occupation because they lack the required skills. ${ }^{26}$ As a result, hopelessness and depression is widespread in the community in general and among the youth of the community in particular. Most of the youth are addicted to local beer and they do not respect their elders and parents. Empirical data show that some youngsters even go to the extent of beating their parents and stealing their pension money. Along with these problems, the community also experiences murder, rape, adultery and theft. ${ }^{27}$

The other source of conflict among the San people in Platfontein is a deep-rooted leadership problem.

The problem between the !Xu and the Khwe is really a leadership problem ... The Khwe were in the majority by far when they were in the SADF, so they were the powerful people. There was apparently quite a bit of status involved with being Khwe. Now, the! Xu are the majority. That shift is uncomfortable for the Khwe. ${ }^{28}$

Though this information was given 13 years ago, unfortunately the problem has not yet been addressed. The San people who lived in different parts of Southern Africa were made to settle in one area as a community. The !Xun from southern Angola and the Khwe from northern Botswana and southern Angola were brought together in the 1970s by the European colonisers because of the wars against those fighting for the independence of Angola and Namibia. However, none of the groups are happy about their relationship with one another:

Desert of the Skeletons.

GOA, Interview with M J. Platfontein, Block: Platfontein Knowledge Centre (14 May 2014) San Dispute Resolution Oral Archive (SANDROA), http://hdl.handle.net/10500/14042.

Open Society Initiative for Southern Africa (OSISA), Fighting for survival, 2014, http://www.osisa.org/indigenous-peoples/regional/fighting-survival

MaOA, Focus Group Discussion, Platfontein, (June 2014).

Chennells, in Steven Robins, Elias Madzudzo \& Matthias Brenzinger, An Assessment of the Status of the San in South Africa, Angola, Zambia and Zimbabwe, 2001, www.lac.org.na/projects/lead/Pdf/sansazz.pdf p.21. 
"Incidents of violence between the !Xun and Khwe increased in intensity and cruelty." ${ }^{29}$ The San people themselves say that "in the beginning, when we merged with this community, there was no understanding of each other, and this situation has continued to this day." ${ }^{30}$ Another respondent also contends that "We have different backgrounds and we come from different places. The problems of the past still exist." ${ }^{31}$ There is no mutual respect, trust and understanding within the community, and the community does not trust the existing leadership. They believe that "currently the leaders in Platfontein take their own benefit instead of uplifting the community and improve the future of the youth and the community." 32 The leadership is blamed for being partial; hence, some members of the community do not give it due recognition. Claiming that it had its own traditional leader in its old settlement, every sub-clan within the !Xun and Khwe wants to appoint a community leader from their group so that the sub-clan members' socioeconomic benefit will be adequately ensured. In the words of one of the interviewees: "In the past, we only know few leaders. Now, when we resettle in South Africa, they are forming themselves leaders ... When we come to a real leader, they fail to recognise changing oneself into a leader. That causes an irresolvable conflict." ${ }^{33}$

\section{Conflict resolution mechanisms and practices of the San}

Any conflict that cannot be settled by the disputants themselves or through the support of their close relatives or friends is referred to the clan's traditional leader. However, before the case is referred, the applicant needs to have sufficient evidence to prove that his claim is valid. For this reason, adequate time is given to collect reliable evidence which proves the applicant is indeed the victim of the accused. In this regard, their motto seems to be that a "slow and steady" approach will eventually be successful.

Due to their inherent harmlessness and the respect they have for human beings, murder among the San people is rare. They are scared to see a person dying. One of the research participants says that they are "afraid of killing people and seeing people dying." ${ }^{34}$ Regardless of this, when murder happens, the victim's family does not directly rush to revenge. Revenge becomes an option when the killer and his family refuse to come to the endogenous court hearing. In that case, any family member of the deceased can avenge the murder.

Following the funeral ceremony, the family of the deceased person do their best to access and assess all evidence of who did the murder; why he did it; and how, where and when he did it. Then they go back and investigate the historical relationships they have had with the family

David Robbins, On the Bridge of Goodbye :The Story of South Africa's Discarded San Soldiers, Jonathan Ball, Johannesburg and Cape Town, 2007, p.37.

0

MOA, Focus Group Discussion, Platfontein, (25 March 2014).

$\mathrm{DaOA}$, Interview with F M, Platfontein, (21 May 2014).

SOA, Interview with M S. Block: Morosani Street, Platfontein, (23 March 2014) San Dispute Resolution Oral Archive (SANDROA), http://hdl.handle.net/10500/14060.

GOA, Interview with M J. Platfontein, Block: Platfontein Knowledge Centre (14 May 2014) San Dispute Resolution Oral Archive (SANDROA), http://hdl.handle.net/10500/14042.

GOA, Interview with Z S. Block: Platfontein Knowledge Centre, (14 May 2014) San Dispute Resolution Oral Archive (SANDROA) http://hdl.handle.net/10500/14045.

TD, 10(4), December 2014, pp. 84-98. 
of the slayer. Having all the necessary evidence, the family of the deceased person present their appeal to their traditional leader indirectly, through his spokesperson, by saying: "we want to hear what the actual problem was; why our family member was killed. So, we want the traditional leader to question the accused so that all could hear because we have lost a body." ${ }^{35}$

Then the spokesperson in turn delivers the appeal to the traditional leader. As soon as the traditional leader receives the appeal, he orders his spokesperson to proclaim the court hearing date that the traditional leader has arranged to the disputants, the tribal police and the community at large. Tribal policemen are called to bring the accused murderer to the court in case he refuses to come. After the arrival of the families of disputants and the community members under a big tree which serves as the venue, the endogenous court hearing begins. ${ }^{36}$

Through his spokesperson, the traditional leader orders the victim's family to present their case to the public attending the court hearing. Accordingly, the family of the deceased ask the family of the slayer why they killed a member of their family. Next, the traditional leader, through his spokesperson, questions the slayer's family by asking "Is it true that you have killed the person?" The traditional leader urges the slayer and his family to confess their wrongdoing and to narrate the story of the event. For the San people, if the reconciliation process is to be successful, telling the truth is one of the moral values expected of the public in general and the slayer's family in particular.

The accused family, with humility, either accepts or denies the charge. If they deny it, the victim's family is urged to present its witnesses. If the family of the slayer takes responsibility for the murder, the slayer is ordered to tell the full story of the incident. ${ }^{37}$ If the case is too difficult to address by hearing witnesses for both the victim and the offender, the traditional leader can postpone his verdict until he receives reliable evidence about the incident from independent sources. The traditional leader can assign his assistants to use all appropriate means to obtain crucial evidence for his final decision. For this reason, the conflict resolution process can take weeks or months. ${ }^{38}$ In the past, the truth-seeking process was very harsh. The alleged offender was immersed up to his neck in a pond dug for the purpose, and sometimes accused persons were made to stand barefoot on the hot sand for a long period of time so that they would tell the truth. ${ }^{39}$

After the family of the murderer accept their wrongdoing, the traditional leader tries to show how murder causes pain by saying: "Tell me how these people [the victim's family] feel now". The murderer's family respond: "They feel very bad". The traditional leader also publicly

GOA, Interview with M J. Platfontein, Block: Platfontein Knowledge Centre (14 May 2014) San Dispute Resolution Oral Archive (SANDROA), http://hdl.handle.net/10500/14042.

SOA, Interview with J J. Platfontein, (22 May 2014) \& SOA, Interview with M D. Block: Kamatoka, Platfontein, (21 January 2014) San Dispute Resolution Oral Archive (SANDROA), http://hdl.handle.net/10500/14053.

SOA, Interview with M S. Block: Morosani Street, Platfontein, (23 March 2014) San Dispute Resolution Oral Archive (SANDROA), http://hdl.handle.net/10500/14060.

DaOA, Interview with H C, Platfontein, (22 May 2014).

SOA, Interview with D F. Block: Morosani Street, Platfontein, (28 March 2014) San Dispute Resolution Oral Archive (SANDROA) http://hdl.handle.net/10500/14055. 
affirms that the murderer's family have taken responsibility for the murder by further asking: "Now, do you all accept that you are guilty?" The murderer's family reply "Yes". In this way, the family accepts the consequences as well. Then the traditional leader comes back to the victim's family and says: "As you have heard, they have accepted their wrongdoing. Now, I want to know your suggestion about what should be done". The victim's family usually respond: "Our traditional leader, we brought the case to you so that you would give us your judgment. We have nothing to suggest. Let you give your own decision”. Sometimes, the victim's family may propose what should be done as requested by the traditional leader. With this, the hearing proceeds to its verdict. Though the ultimate decision is that of the traditional leader, the public in general and the leaders under supervision of the traditional leader in particular are allowed to make suggestions about the case they have attended. Their suggestions serve as immediate input for the traditional leader when he decides on his final verdict. ${ }^{40}$

Verdicts for murder cases in the old days were very serious. In some cases, a murderer would be sentenced to death. ${ }^{41}$ There was also an occasion when an offender was sold by the traditional leader so that the victim's family could be compensated. ${ }^{42}$ These days, however, the endogenous court hearing de jure makes a murderer a lifelong servant of the victim's family. The intention behind this verdict is to make the murderer take the place of the deceased by offering all the services to the victim's family that the deceased would have offered. De facto, however, the murderer gives some compensation both in kind and/or in cash till the victim's family says "that is enough". Bows and arrows, beads, cattle and processed animal skins are some of the items given as compensation in kind. The compensation is usually paid in instalments within a certain period of time through an agent assigned by the traditional leader. The agent receives the compensation from the murderer and gives it to the victim's family. Interrupting payment in the middle of the process has very serious consequences. It may be interpreted to mean "you do not deserve respect and compensation for you cannot defend yourself". As a result, conflict may erupt once again among the disputants. ${ }^{43}$

The murderer's change of behaviour is another pre-condition for successful reconciliation. He has to show genuine regret for his wrongdoing to the victim's family. The murderer is therefore watched for a certain period of time to judge whether he has a positive or negative attitude to the victim's family. After the victim's family have decided that the compensation they received is adequate and the behaviour being demonstrated by the murderer is appropriate, they request their traditional leader to summon the public so that they can declare that they are happy with the compensation and behaviour of the murderer. The

40 GOA, Interview with J M M. Platfontein, Block: Platfontein Knowledge Centre (15 May 2014) San Dispute Resolution Oral Archive (SANDROA). http://hdl.handle.net/10500/14041 \& GOA, Interview with M J. Platfontein, Block: Platfontein Knowledge Centre (14 May 2014) San Dispute Resolution Oral Archive (SANDROA), http://hdl.handle.net/10500/14042.

41 DaOA, Interview with H C, Platfontein, (22 May 2014).

42 GOA, Interview with R D. Pretoria, Block: Roode Valley, (11 July 2014) San Dispute Resolution Oral Archive (SANDROA) http://hdl.handle.net/10500/14044.

43 SOA, Interview with J M. Block: Kamatoka, Platfontein, (21 January 2014) San Dispute Resolution Oral Archive (SANDROA), http://hdl.handle.net/10500/14051; GOA, Interview with R D. Pretoria, Block: Roode Valley, (11 July 2014) San Dispute Resolution Oral Archive (SANDROA) http://hdl.handle.net/10500/14044 \& Desert of the Skeletons.

TD, 10(4), December 2014, pp. 84-98. 
traditional leader does this through his spokesperson, and the victim's family publicly declare that they are happy with the reconciliation process as it has fulfilled the decisions of their traditional leader and has met their interests. ${ }^{44}$

Following this, a short ceremony called "dahakonkn" is staged. It is a final oath by which the disputants declare the reconciliation to be completed successfully. On this occasion, representatives from the murderer's and the victim's sides hold a piece of grass at opposite ends, break it together and throw it away. They also drink water from the same cup. By doing so, both sides proclaim that "From now onwards, the enmity is over." The victim's family says: "bygones are bygones, we are now happy that the murderer has regretted his wrongdoing; he has also offered compensation, which made us all happy". By staging this ceremony, the disputants also indicate: "I am out of you and you are out of me. I cannot come back to you and say you killed my brother. You cannot come to me and say your brother provoked me and I killed him." ${ }^{45}$ On this occasion, the last payment can be collected in public. From this payment, a small amount of money is kept back to supply drink to the traditional leader and his assistants. This process is called "Katuru".Though optional, there could be a feast which marks peaceful settlement of the dispute. The party is prepared by both sides; a goat or cow may be slaughtered and there could be handshaking and dancing. ${ }^{46}$

For the San people, every murder has a similar treatment. No matter what the situation, it passes through the same reconciliation procedures. There is no different treatment for accidental and pre-planned murders; compensation for a murdered man and a murdered woman is equal. "Everything counts the same. Death is death."

Currently, murder cases are taken to the modern justice system of the Republic of South Africa and the verdict is given under the laws of the country. This is mainly done for two reasons: on one hand, the community should be governed by the laws of the country; on the other hand, the endogenous court hearing is not as strong as it used to be. However, after the murderer has completed his legal punishment, he has to go back to the endogenous reconciliation process according to the appeal of the victim's family. In this reconciliation process, the murderer is obliged to pay modest compensation in order to dry the tears of the victim's family. ${ }^{48}$

The San's endogenous conflict resolution mechanism follows more or less the same procedures for all types of conflict at all levels. For example, the procedure for investigating the source and nature of a fight between individuals within a clan is same as the court hearing procedure for murder discussed above. However, there is a tradition of diagnosing the nature and depth of the victim's wounds resulting from the combat. Based on the diagnosis, the offender could be forced to slaughter a goat or a hen for the victim so that he will be healed

${ }^{44}$ GOA, Interview with M J. Platfontein, Block: Platfontein Knowledge Centre (14 May 2014) San Dispute Resolution Oral Archive (SANDROA), http://hdl.handle.net/10500/14042.

GOA, Interview with J M M. Platfontein, Block: Platfontein Knowledge Centre (15 May 2014) San Dispute Resolution Oral Archive (SANDROA). http://hdl.handle.net/10500/14041. Ibid. Resolution Oral Archive (SANDROA) http://hdl.handle.net/10500/14045. 
and his lost blood will be replaced. This step is usually a pre-condition for the main process of solving the matter peacefully through the endogenous court hearing. Offering a goat to the victim obviously declares that the offender regrets his wrongdoing and is ready to resolve the matter through reconciliation. ${ }^{49}$

When the endogenous court hearing reaches the stage of determining the compensation for the victim, the traditional leader first requests a proposal from the victim's side. If they make a proposal, the traditional leader may approve it provided that he is convinced of the fairness of the amount proposed. Otherwise, the traditional leader can allow the offender's family to negotiate the amount of the compensation. ${ }^{50}$ In fact, compensation-related decisions are made based on the nature of the case and the level of damage of the conflict. Compensation for different organs of a body differs: for example, compensation for loss of an eye is higher than that for a tooth, for the service of an eye is greater than the service of a tooth. ${ }^{51}$ For instance, one of the research participants narrates the verdict given in one case in which he participated as a spokesperson of his clan's traditional leader:

There was a case of one lady whose son had a fight with an individual from another clan. They broke his teeth. They brought it to me and I took it to our traditional leader Komamo. Then, Komamo decided that he could handle the case. Then he took it to the traditional leader of the other clan. They sat and discussed the matter. The parents of the offender accepted the problem but they had no money because of the poverty. Their son will go to farm to work there then they are going to collect the money from him. Then they will pay them back. ${ }^{52}$

The traditional leader decided that the victim who lost three teeth in the fight was to be compensated R10 000. Sometimes corporal punishment is also applied if the offender cannot pay and has no one to help him pay the compensation. Under-age offenders can be forced to drink a bucket of water as punishment. ${ }^{33}$ There is also a cleansing ceremony in which a goat is slaughtered, and then the offender and the wound of the victim are smeared with the blood. ${ }^{54}$

If a family's case is beyond the capacity of husband and wife, the case is taken to the clan's traditional leader. With this it becomes an intra-clan level conflict (provided that the people involved are from the same clan). Subsequently, the matter is investigated by the traditional leader along with his assistants both informally and formally. The informal investigation of

GOA, Interview with M J. Platfontein, Block: Platfontein Knowledge Centre (14 May 2014) San Dispute Resolution Oral Archive (SANDROA), http://hdl.handle.net/10500/14042 \& GOA, Interview with Z S. Block: Platfontein Knowledge Centre, (14 May 2014) San Dispute Resolution Oral Archive (SANDROA) http://hdl.handle.net/10500/14045.

MOA, Interview with M P. Sula Street, Platfontein, (20 May 2014) San Dispute Resolution Oral Archive (SANDROA) http://hdl.handle.net/10500/13918.

GOA, Interview with R D. Pretoria, Block: Roode Valley, (11 July 2014) San Dispute Resolution Oral Archive (SANDROA) http://hdl.handle.net/10500/14044.

GOA, Interview with Z S. Block: Platfontein Knowledge Centre, (14 May 2014) San Dispute Resolution Oral Archive (SANDROA) http://hdl.handle.net/10500/14045.

ShOA, Interview with S T. Block: Morosani Street, Platfontein (n.d) San Dispute Resolution Oral Archive (SANDROA), http://hdl.handle.net/10500/13948. 
the accused individual is made by the agent of the traditional leader without the accused having knowledge of being observed. If the observer thinks that he can solve the problem he tries to settle the dispute, usually by giving advice to both parties based on his observations. Otherwise, he reports the result of his observations to the traditional leader, and with this input the formal endogenous court process ensues.

Normally, in the process of investigation, the offender is expected to confess. Confessing is usually seen as a way of expressing the offender's willingness to settle the matter through the endogenous court. Therefore it makes its own positive contribution to the verdict that will eventually be given by the traditional leader. As soon as the investigation is over and the guilty party revealed, in a case of adultery, the traditional leader requests a statement by the victim on the relationship she or he will have with the offender in future. The victim declares whether he or she wants to stay with his or her partner regardless of her or his wrongdoing for he or she still loves the partner. After the interest is revealed, the compensation for the victim is proclaimed by the traditional leader through his spokesperson. If the offender is the husband, he is urged to give cattle to the wife's family. If the offender is the wife, her family will be forced to return all the cattle and services offered to them by the husband by virtue of their being parents of the wife. The compensation which is paid to the victim's husband may also come from the man who committed adultery with the woman. ${ }^{55}$

The dispute resolution practices of the San at inter-clan stage basically follow the same procedures as the intra-clan level conflict resolution processes discussed above. What makes them a bit different from the intra-clan level proceedings is the identity of the traditional leader who gives the judgment. In an inter-clan conflict, the victim's family reports the case to the clan's traditional leader and the traditional leader takes the case to the traditional leader of the offender. They discuss the matter and then the judgement is given by the offender's traditional leader, following the endogenous conflict resolution procedures narrated above. In fact, the offender's traditional leader gives his judgement under close scrutiny of the victim's traditional leader. If the traditional leader of the offender is not strong, he may pass the case to the leader of the victim. The venue is usually in the offender's vicinity unless the offender's traditional leader has a bad track record in his judgments. The victim's family may also say "let the offender's family come here; we do not go there."

\section{Current status of the conflict resolution institution}

Regardless of its ability to resolve disputes in a short period of time and its being culturally appropriate, "the endogenous court is not active like it was in the past" Khwe joint council which was established at Schmidtsdrift is no longer functional due to lack of mutual trust, cooperation and understanding between the communities. Similarly, the majority of the population from both clans does not trust the existing traditional leadership, for the community believes that every small group is claiming leadership to maintain family

55 GOA, Interview with Z S. Block: Platfontein Knowledge Centre, (14 May 2014) San Dispute Resolution Oral Archive (SANDROA) http://hdl.handle.net/10500/14045. 
and small-group interests instead of working for the community as the whole. The community seems confused about where to refer dispute cases to. They don't "know who is in charge of the traditional court because the leaders are many." ${ }^{58}$ Another reason for showing less interest in their endogenous conflict resolution mechanism is the influence of other neighbouring communities' culture. The majority of the community members, especially the young generation, follow Western culture. Hence, they prefer the modern justice system to endogenous conflict resolution mechanisms. ${ }^{59}$

This being so, however, currently the !Xun San have their own council which is led by their traditional leader. They use the endogenous court hearing to resolve intra-clan level minor disputes. ON the other hand, the Khwe San prefer to take their intra-clan disputes to their respective churches. ${ }^{60}$ "The church people are now the people who encourage others to fix relationships by giving the parties involved the word of God."

\section{Gender issues in the endogenous conflict resolution mechanisms}

Historically, the hunter-gatherer San communities in Southern Africa were known for their egalitarian social structures. Taking into account the economic inequality between men and women; the use of physical violence to resolve conflict; male authority and control of decision-making in the house; and restrictions on women's access to divorce, Levinson has ranked the San one of six non-Western societies in the world that had little family violence. ${ }^{62}$ The main duty of a man was hunting and making fire, but a woman was responsible for gathering food, taking care of children and building shelters. While this is so, a woman could help in hunting and a man could be involved in gathering plants for food, so there were no strictly observed gender roles in the community.

The absence of a strict gender-based division of tasks could help women participate equally in decision-making processes. Women were as active participants as men in the communitylevel court hearings. They could present their case to the court and they could also make suggestions in public. "These societies were relatively gender-egalitarian in the economic sphere and with respect to community decision-making, and they generally had sophisticated means of peaceful conflict resolution." ${ }^{\text {"3 }}$ However, these egalitarian social structures are gradually being eroded. The change is mainly attributed to the recent socioeconomic dynamics within the community. As women's role in socioeconomic activities decreases, the

58 DOA, Interview with K M. Block: Kamatoka, Platfontein, (21 May 2014) San Dispute Resolution Oral Archive (SANDROA), http://hdl.handle.net/10500/13949.

DOA, Interview with L S. Block: Kamatoka, Platfontein, (22 May 2014) San Dispute Resolution Oral Archive (SANDROA) http://hdl.handle.net/10500/13954.

GOA, Interview with H S. Pretoria, Block: Roode Valley, (12 July 2014) San Dispute Resolution Oral Archive (SANDROA), http://hdl.handle.net/10500/14040.

ShOA, Interview with R K. Block: Tseringu Street, Platfontein (n.d) San Dispute Resolution Oral Archive (SANDROA), http://hdl.handle.net/10500/13946.

Levinson, Family violence in cross-cultural perspective: Frontiers of Anthropology, Vol. 1, Sage Publications, Newbury Park, CA, 1989, pp.102-103.

Silke Felton \& Heike Becker, A Gender Perspective on the Status of the San in Southern Africa, 2001, www.lac.org.na/projects/lead/Pdf/sangend.pdf p.56. 
likelihood of their being dependent on their men increases. Unlike in the past, women are becoming dependent on men due to sedentarisation, pastoralism, wage labour, maledominated neighbouring communities and the militarisation of San life. ${ }^{64}$ As to the social organisation of the San community at Platfontein, it "clearly matches Levinson's four predictors for a society prone to family violence, namely: gross economic inequality between men and women; male authority in domestic decision-making; women's difficulties in obtaining divorce (because of their dependency); and a pervasive culture of violent conflict resolution." 65

\section{Conclusion}

The focus of the San people's conflict resolution practice is on restoring the community's peace and security. To this end, the community uses both modern and endogenous conflict resolution practices in such a way that one complements the other. For example, a murder case usually goes through both the state's justice system and the endogenous conflict resolution institution of the community. This practice is vital for lasting peace and harmony in the community at large and for the families of the disputants in particular.

As a culture, following damage caused by a conflict, the San people do not rush to revenge. Instead, they take due time to investigate the case deeply. After collecting all the necessary evidence, they take their case to their traditional leader. Revenge is taken as a last option if the offender's family refuses to come to the endogenous court hearing. The San's endogenous conflict resolution mechanisms are fairly participatory; they allow leaders under the traditional leader, men and women to attend the court hearing and make suggestions during the proceedings.

Currently, however, the community's affinity for this endogenous conflict resolution mechanism is decreasing. This problem is mainly attributed to the impact of modernisation and the community's leadership problems. So, if the community is to continue using its endogenous conflict resolution institution in harmony with the state's justice system, the institution has to be made more participatory and gender-sensitive. In particular, the youth should be encouraged to participate in endogenous court hearings. Women's involvement in the conflict resolution mechanisms should also be strengthened. More importantly, the community's confidence in the endogenous conflict resolution institution and its traditional leadership should be enhanced. This could be done through arranging consultative meetings and workshops which bring representatives of all clans and sub-clans together. In the meetings, discussants should be encouraged to talk about the root causes of their misunderstandings among themselves and to put forward possible solutions for their problems. Re-establishing a council of the San community that represents all sub-groups democratically could be one possible solution to the traditional leadership problem. The council members and the community's traditional leader, who will be elected from the council, should hold their positions for a certain period of time, which is decided by the assembly of the community.

Felton \& Becker, op.cit., p.57. 


\section{References}

\section{Primary Sources}

Dakane Oral Archive (DaOA), Interview with F M. Platfontein, (21 May 2014). , Interview with H C, Platfontein, (22 May 2014).

Dixon Oral Archive (DOA), Interview with K M. Block: Kamatoka, Platfontein, (21 May 2014) San Dispute Resolution Oral Archive (SANDROA), http://hdl.handle.net/10500/13949. Interview with L S. Block: Kamatoka, Platfontein, (22 May 2014) San Dispute Resolution Oral Archive (SANDROA) http://hdl.handle.net/10500/13954.

Gebregeorgis Oral Archive (GOA), Interview with H S. Pretoria, Block: Roode Valley, (12 July 2014) San Dispute Resolution Oral Archive (SANDROA), http://hdl.handle.net/10500/14040.

, Interview with J M M. Platfontein, Block: Platfontein Knowledge Centre (15 May 2014) San Dispute Resolution Oral Archive (SANDROA). http://hdl.handle.net/10500/14041.

, Interview with M J. Platfontein, Block: Platfontein Knowledge Centre (14 May 2014) San Dispute Resolution Oral Archive (SANDROA), http://hdl.handle.net/10500/14042.

, Interview with R D. Pretoria, Block: Roode Valley, (11 July 2014) San Dispute Resolution Oral Archive (SANDROA) http://hdl.handle.net/10500/14044.

, Interview with Z S. Block: Platfontein Knowledge Centre, (14 May 2014) San Dispute Resolution Oral Archive (SANDROA) http://hdl.handle.net/10500/14045.

Mahongo Oral Archive (MOA), Interview with M P. Sula Street, Platfontein, (20 May 2014) San Dispute Resolution Oral Archive (SANDROA) http://hdl.handle.net/10500/13918.

, Focus Group Discussion, Platfontein, (25 March 2014).

Mangumbu Oral Archive (MaOA), Focus Group Discussion, Platfontein, (June 2014).

Shiwarra Oral Archive (ShOA) Interview with S T. Block: Morosani Street, Platfontein (n.d) San Dispute Resolution Oral Archive (SANDROA), http://hdl.handle.net/10500/13948.

, Interview with R K. Block: Tseringu Street, Platfontein (n.d) San Dispute Resolution Oral Archive (SANDROA), http://hdl.handle.net/10500/13946.

Sibongo Oral Archive (SOA), Interview with D F. Block: Morosani Street, Platfontein, (28 March 2014) San Dispute Resolution Oral Archive (SANDROA) http://hdl.handle.net/10500/14055.

Interview with J J. Platfontein, (22 May 2014). 
Interview with J M. Block: Kamatoka, Platfontein, (21 January 2014) San Dispute Resolution Oral Archive (SANDROA), http://hdl.handle.net/10500/14051.

, Interview with M D. Block: Kamatoka, Platfontein, (21 January 2014) San Dispute Resolution Oral Archive (SANDROA), http://hdl.handle.net/10500/14053.

, Interview with M S. Block: Morosani Street, Platfontein, (23 March 2014) San Dispute Resolution Oral Archive (SANDROA), http://hdl.handle.net/10500/14060.

, Interview with T M. Block: Morosani Street, Platfontein, (22 May 2014) San

Dispute Resolution Oral Archive (SANDROA), http://hdl.handle.net/10500/14079.

\section{Secondary Sources}

Broyhill, K, Hitchcock, R \& Biesele, M., Current situations facing the San Peoples of Southern Africa, (2010) http://www.kalaharipeoples.org/resources.htm.

Chennells, R \& Du Toit, A., "The rights of indigenous peoples in South Africa”, in R Hitchcock \& D Vinding (eds), Indigenous Peoples' Rights in Southern Africa, IWGIA. (2004) www.iwgia.org/iwgia_files.../0119_SouthernAfricaDoc110Complete.pdf.

"Desert of the Skeletons", (2013) http://www.youtube.com/watch?v=J2UXX9yAQGY.

Economic Commission for Africa (ECA), Relevance of African traditional institutions of governance, (2007) http://www.uneca.org/sites/default/files/publications/ relevance_africantradinstgov.pdf.

Felton, S \& Becker, H., A gender perspective on the status of the San in Southern Africa, (2001) www.lac.org.na/projects/lead/Pdf/sangend.pdf.

Jenkins, O., The !Kung Bushmen, (2006) http://orvillejenkins.com/profiles/kung.html.

Kwekudee, Trip down memory lane, (2013) http://kwekudeetripdownmemorylane.blogspot.com.

Levinson, D., Family violence in cross-cultural perspective, Frontiers of Anthropology, vol. 1 (Newbury Park, CA: Sage Publications, 1989).

Open Society Initiative for Southern Africa (OSISA), Fighting for survival, (2014) http://www.osisa.org/indigenous-peoples/regional/fighting-survival.

Robbins, D., On the bridge of goodbye: The story of South Africa's discarded San soldiers, (Johannesburg and Cape Town: Jonathan Ball, 2007).

Robins, S, Madzudzo, E \& Brenzinger, M., An assessment of the status of the San in South Africa, Angola, Zambia and Zimbabwe, www.lac.org.na/projects/lead/Pdf/sansazz.pdf.

South African History Online (SAHO), San hunter-gatherer society in the Later Stone Age, (2000) http://www.sahistory.org.za/people-south-africa/san.

South African San Institute (SASI), Background, http://www.san.org.za/background.php. History, (2009) http://www.san.org.za/history.php. 